Elizabeth A. Buchanan and Dennis Ocholla:

\title{
Introduction: Teaching Information Ethics
}

\section{Authors:}

Prof. Elizabeth A. Buchanan, Ph.D.:

- Endowed Chair and Director, Center for Applied Ethics, University of Wisconsin-Stout, Menomonie, Wisconsin, 53012, USA

- $\widetilde{\mathbb{m}}+1$ - 715 - 232 5184, $ه$ buchanane@uwstout.edu

- Relevant Publications:

- Buchanan, E. and Britz, J. (2010). Ethics from the Bottom-Up? Immersive Ethics and the LIS Curriculum. Journal of Information Ethics 19 (1), 12-19.

- Buchanan, E. and Ess, C. (2009). Internet Research Ethics and the Institutional Review Board: Current Practices and Issues. Computers and Society, 39 (3) 43-49.

- Buchanan, E. and Hvizdak, E. (2009). Online Survey Tools: Ethical and Methodological Concerns of Human Research Ethics Committees. Journal of Empirical Research on Human Research Ethics (JERHRE) 4(2), 37-48.

- Buchanan, E. (2009). Academics and Reflection: A Guest Editorial. Journal of Information Ethics, $18(1), 3-5$.

Prof. Dennis Ocholla, Ph.D.:

- Head of the Department of Information Studies and Vice Dean Faculty of Arts, University of Zululand, X1001, Kwadlangezwa, Richardbay, South Africa.

- 疋 +27035 9026484, $ه$ docholla@pan.uzulu.ac.za

- Relevant Publications:

- Ocholla, Dennis N.; Onyancha Omwoyo Bosire and Johannes Britz.( 2010). Can information ethics be conceptualized by using the core/periphery model? Journal of Informetrics.4,492502 [Online] doi:10.1016/j.joi.2010.05.001

- Mutula, Stephen and Ocholla Dennis (2010), Building Trust in e-Government: A Proposal for an Integrated Model. Mousaion, Vol.28(1), 128-148

- Ocholla, Dennis N. (2009) Information Ethics Education in Africa. Where do we stand? International Information and Library Review, Vol.41,2,79-88

- Ndwandwe Sipho, Ocholla Dennis and Dube Luyanda (2009), Information Ethics Education in Library and Information Science Departments/Schools in South Africa. Mousaion, Vol.27(2), 75-88

- Ocholla, Dennis N. (2007) Marginalized Knowledge: An Agenda for Indigenous Knowledge Development and Integration with other Forms of Knowledge. International Review on Information Ethics, Vol.7.[Online] http://www.i-r-i-e.net 
In this issue we explore different aspects of teaching information ethics. The research base around IE is solid, and fortunately, continually growing. We have considerable understanding of the types of research ongoing across the world in IE. We are also aware of the many fruitful networks of IE scholars, including the most recent, African Information Ethics Network (ANIE). And yet, our sharing of experiences in how we teach, what we teach, how and why students learn and engage best remains virtually unexplored in our field. This is problematic, as our responsibilities as scholars included teaching the next generation of professionals and scholars. Through our teaching, we mentor and we influence. While this issue presents enlightening experiences from our colleagues across a range of issues, from academic freedom to online identity to issues of teaching ethics in an "information school," we are missing experiences from many cultural and pedagogical viewpoints.

To this end, we would like to encourage more sharing among our colleagues who are teaching information ethics. As Capurro rightly notes, "...the concept of Information Ethics itself is changing very quickly. It started as concerning (mainly) the Internet (as cyberethics etc.) and closely related to professionals (particularly computer professionals and LIS professionals) but it became also very quickly clear that this is an issue that concerns society in different ways and cannot be restricted to issues of professional ethics. This became evident since the Internet developed into a social space. Many digital technologies (most of them connected with the internet) are having a big impact on societies but they are not directly concerned with questions of freedom of speech, copyright etc. but with the life of the people as individuals (with their bodies, particularly, for instance in case of implants) and with new applications in the field of robotics, bionics etc. that broaden the scope of "information" beyond the field of knowledge (its storage, transmission etc.) into other areas and disciplines so that IE becomes an interdisciplinary topic" (2011). With this in mind, we see exponential potential for teaching in the field of IE.

As we explore the papers in this issue we take note of Toni Samek's, Teaching Information Ethics in Higher Education: A crash Course in Academic Labour" that builds on her earlier personal accounts, "Talking about Information Ethics in Higher Education" published in the Journal Information for Social Change and a short column titled "Tested Teaching" published in the Journal of Information Ethics, by "extending the discussions into a deeper exploration of the academic labour that frames conditions for teaching information ethics. Without recognizing the importance of supportive conditions, our efforts to teach relevantly and relevant issues is undermined.

David J. Saab, paper on "Teaching Information Ethics in an iSchool," provides useful practical information on how to develop and deliver an "information ethics course, paying attention to student receptivity and learning, course structure and assignments, as well as its connection to the wider curriculum and its efficacy." While specifically situated in an "i-school," Saab's advice is generalizable beyond those settings.

Michael Zimmer's paper "Innovations and Challenges in Teaching Information Ethics Across Educational Contexts" explores the need for teaching IE at all educational levels and the challenges that occur at these diverse settings. His paper is based on a 2011 Association of Library and Information Science Educators (ALISE) panel discussion and "offers recommendations towards achieving success in information ethics education."

Miguel Alvarez observes the impact of social communities on scientific practices. He argues that the epistemic figure of self-reflection is a guiding principle of virtual scientific communities and thus a moral imperative to its members - reinforced by the technologies enabling web 2.0 communities.

Finally, we include Stephen Mutula's article entitled, 'A framework for Integrating Information Ethics (IE) in the Curricula for Africa, that recognises the debate about integrating IE in LIS curriculum in the region. Still problematic and contested, however, is the issue of which theoretical framework such discussions should be based in the IE content and context for Africa.

After finalizing the issue we took note of and were discussing the reasons for the strongly varying amount of contributions from the different cultural regions of the world. With respect to the emergence of strong regional IE networks in Africa we were grateful to the report Coetzee Betzer, Executive Director of ANIE, contributed in the course of that discussion. Encouraging more activities in this regard we subsequently included his report in this issue. 